\title{
How Entrepreneurship Can Be Learned through Experiential Learning Formats, Especially through Training Firms
}

\author{
Dr. Anne Heinze \\ Hochschule für Technik und Wirtschaft Berlin, Germany
}

\begin{abstract}
:
A look at entrepreneurship education research shows that there are basically two types of entrepreneurship courses: First, courses for entrepreneurship and second, courses about entrepreneurship such as lectures, formal seminars, individual essays etc. Most of the latter courses can be characterized as teacher-centric where the student involvement is passive. From a more modern perspective and in order to train entrepreneurs trying, experimenting and learning about one's own experience is crucial. More innovative approaches, such as project-based learning, action-based learning and experiential learning, therefore, are gradually appearing on the scene In this context, within the last few years some universities have introduced training firms, mostly for students of economics and business. In Germany, due to a lack of legal possibilities training firms at public universities are still a rarity and therefore underresearched. Thus, the research question for the present contribution is how informal learning can be structured using training firms, and what effects this has on the preparation of learners for later professional practice and / or self-employment.

Therefore, the methodology for this paper is first to review the literature related to entrepreneurial learning in order to better understand the informal learning experience in training firms. Second, the case of a communication design agency for students around HTW Berlin, a public university for applied sciences, is analyzed to gain insight into the impact that practice firms can have on entrepreneurship education in general, and in particular in non-business subjects. For this purpose, a case study has been developed based on interviews, which include both the perspective of the students and of the trainer. Overall, the results will show a best practice example of entrepreneurial training and learning in a university context, which can be useful for those involved in the development of course concepts for entrepreneurship education.
\end{abstract}

Keywords: Entrepreneurship Education; Informal Entrepreneurial Teaching; Experiential Learning; Training Firms

Received: 30 Sept 2020

ISSN 2056-757X

Revised: 22 October 2020

Accepted: 9 Nov 2020

https://doi.org/10.18646/2056.74.20-033 


\section{Introduction}

The traditional entrepreneurship education school was primarily shaped by the idea that entrepreneurship can be taught through teaching start-up-related content. However, more recent approaches show that to be a good entrepreneur you need to be experienced in entrepreneurship. Therefore, approaches in entrepreneurship education that make entrepreneurship tangible are gaining importance. This also includes projectbased learning, action-based learning and experiential learning. Generally, these approaches better prepare alumni for future challenges in their jobs and or selfemployment activities than more traditional approaches.

This paper tries to shed more light on experiential and application-based learning in entrepreneurship education. In this context, training firms offer the opportunity to implement project and experience-based learning approaches into the curricula of the students. Thus, the research question for the present article is how informal learning can be structured by instructors using training firms, and what effects this has on the preparation of the learners for later professional practice and / or self-employment.

First, and in order to achieve the research objective mentioned above, the current status of research on entrepreneurship education - with special consideration of modern approaches such as project-based and action-based learning as well as experiential learning - is presented. In addition, the informal learning experience through training companies is clarified. Second, the case of a communication design agency for students around University of Applied Sciences HTW Berlin is analyzed to gain insights into the impact that practice firms can have on entrepreneurship education in general, and in particular in non-business subjects. For this purpose, a case study has been developed based on interviews, which includes both the perspective of the students and of the trainer. The interviews are conducted according to interview guidelines.

The results provide insights into the necessary framework conditions and demands on teachers and learners when implementing a training firm at a public university for applied sciences. All in all, the results will show a best practice example of entrepreneurial training and learning in a university context, which may be useful for lecturers involved in the development of course concepts for entrepreneurship education in academia.

\section{Theoretical Background}

Research on entrepreneurship education has shown that there are basically two types of entrepreneurship courses: First, courses for entrepreneurship and second, courses about entrepreneurship such as lectures, formal seminars, individual essays etc. (Levie 1999: 3, 18; Manimala and Thomas 2017: 10). Common entrepreneurship courses usually offer learning about entrepreneurship. Most of these courses can be characterized as teacher-centric, where the student involvement is passive. Such courses are usually offered by Startup Service Centers at universities on an extracurricular basis (students who take part in these courses generally do not receive credit points for this additional commitment). But - although that is exactly what such

International Journal of Management and Applied Research, 2020, Vol. 7, No. 4 
courses are usually about - entrepreneurship is not linear, but a complex process that cannot be learned through mere content (Linton and Klinton 2019: 1).

However, more modern approaches assume that entrepreneurship can only be achieved by trying, experimenting and learning about one's own experience (Ebbers 2004: 35). This is because according to newer approaches motivating students to become and / or think as entrepreneurs is key. And you cannot create motivation by just teaching mere content. In contrast, real life experiences and role playing are better suited to achieve this learning goal. In order to promote entrepreneurial thinking and behaviour, the learning environment must therefore be designed differently and contain not only, for example, inspiring personalities and successful start-up examples, but also offer opportunities to make the requirements for starting a company tangible. All in all, the learning environment must enable experiences in the "real world" as part of good entrepreneurship education (Pittz 2014: 182). This is why more innovative educational approaches, such as project-based learning, action-based learning and experiential learning are gradually appearing on the scene in the context of entrepreneurial teaching and learning (Hills et al. 2007: 226). The learning environment of the latter concepts is marked by student-centric content, experience-based and action-oriented projects and includes, for example, case studies, cooperation with practitioners, simulation exercises, practical workshops, and group projects (Levie 1999: 18; Manimala and Thomas 2017: 10).

To further clarify the above-mentioned concepts, it can be stated that experiential learning is characterized by students playing an active role in the learning process (Sukavejworakit et al. 2018: 2). Furthermore, experiential learning is particularly about the creation of processes with open results (Lackeus and Williams Middleton 2018: 20). For this reason, fixed learning objectives cannot be formulated in advance. The only things that can be monitored and determined by the trainer are certain framework conditions for the processing and implementation of a project (topics, target groups, deadlines, etc.).

In this context, project-based learning is to be understood as a learning format that "[...] places students in realistic contextualized problem-solving learning environments" (Blumenfeldt et al. 1991: 372). Project-based learning is particularly successful when interdisciplinary teams are put together to work on a project. This enables a comprehensive view of a topic and its context including many different perspectives. The team should have the greatest possible autonomy in structuring the project and the approach to processing the project. In addition, also here only certain framework conditions such as processing time and the way the results are presented should be specified in advance.

The third approach, action-based learning, is based on real life experience. This includes, for example, experience of a real-life venture creation environment provided within the protected framework of a university. In this protected space, the students can try out real tasks and jobs applying the knowledge gained through their studies without failure or mistakes having negative consequences (Lackeus and Williams Middleton 2018: 28-29). This type of learning environment also applies to training firms, even if they also include aspects of experience-based and project-based learning.

International Journal of Management and Applied Research, 2020, Vol. 7, No. 4 
The effect of student engagement in training companies as a special type of action learning has frequently been analyzed for students from business-related subjects. In contrast, the impact on non-business students has so far had a minor role in entrepreneurship education research.

Learning concepts can not only be implemented in teaching units that take place in university, but can also be used beyond that environment. In this context, a distinction is made between formal and informal learning settings. Formal learning takes place in a formally organized manner, for example in the classrooms of universities, whereas informal learning can be undertaken beyond this, for example during an internship, in the new media, in social movements and in leisure activities in general (Overwien 2009: 23). Nowadays we know that many key competencies such as social competencies or the so-called "soft skills" are hardly being learned in a formal way, but are acquired much better in informal learning environments. Incidental learning, i.e. learning without pursuing a specific pre-formulated objective, is also relevant in this context; however, it all depends on the student's commitment. Thus, as the learning context is not formalized they have to act on their own initiative and take responsibility for their own learning; additionally, a certain proactivity is necessary (Overwien 2009: 24). If students are used to formal learning settings, they could easily be overwhelmed by these requirements. Because of this, such settings may not be suitable until later in the course of studies, or should be based on previous experience of the students with self-structured learning formats.

In the context of entrepreneurship education, the Finnish team academy approach has gained more importance in academia as an informal learning setting. Fundamentally, in team academies students work in teams where they learn to run their own businesses with real money and real customers (Fowle and Jussila 2016: 1). The approach has also been adapted for the UK: at Newcastle Business School at the University of Northumbria, for example, there is a work-based approach to learning which supports a philosophy of 'learning by doing', with participants setting up real businesses in teams (Blackwood et al.: 1). In Germany, Bremerhaven University of Applied Sciences has established the Bachelor course "Gründung, Innovation, Führung" where students learn through managing cooperatives, identifying business opportunities and developing plans to further expand their businesses. Setting up training firms at universities is based on similar approaches.

In Germany, however, the establishment and sponsorship of a for-profit company as a training company in higher education is difficult. This is due to the fact that German universities are traditionally publicly financed and state subsidized and therefore the establishment of a profit-oriented business under the same roof is not permitted due to tax regulations. In comparison to other European countries, the marketization of higher education Germany is still far behind (Mueller-Carmen and Salzgeber 2005: 275). Despite these challenges, some training firms have been set up by universities in Germany in recent years, but mostly for students of economics and business. They are often formally maintained by professors who are liable for them through their private assets. The legal restrictions in Germany are probably the reason why, firstly, there are hardly any training firms in general and for non-business subjects in particular at German universities and why, secondly, the effects of possible student engagement in

International Journal of Management and Applied Research, 2020, Vol. 7, No. 4 
such companies in entrepreneurship education research have only little been researched. The present paper aims to close this gap of research using the example of "sehen und ernten e.V." - a design agency in student hands in the surroundings of University of Applied Sciences HTW Berlin which carries out real orders - and analyzes the impact that practice firms can have on entrepreneurship education in general and in non-business subjects in particular.

\section{Methodology}

To fully answer the research question for this article, how informal learning can be structured by instructors using the concept of training firms, and what effects this has on the preparation of learners for later professional practice and / or self-employment, a case study on the above-mentioned example of the design agency "sehen und ernten e.V." was developed. "Sehen und ernten e.V." (www.sehenundernten.org) is a creative agency for conception and design, in which students of communication design come together to work on real orders. It offers students of the University of Applied Sciences HTW Berlin the opportunity to get in touch with the professional world during their studies and to apply what they have already learned during their studies. The HTW Berlin is the largest public University of Applied Sciences in Berlin and Eastern Germany.

In order to include the perspectives of both instructor and students in answering the above research question, three interviews were carried out by the author - one with the teacher of a preliminary tutorial for students interested in participating in the design agency and two more interviews with students who attended the course and later became involved in the design agency. In the following, the interview guidelines for the interviews will be described in more detail in order to precisely document the qualitative research process (Steinke, 2012: 325). To capture the instructor's perspective as well as that of the students, different guidelines were used by the author.

The guideline for the interview with the instructor of the preliminary tutorial consisted of the following aspects:

- motivation to offer the tutorial at the University of Applied Sciences HTW Berlin,

- background and professional experience,

- pedagogical suitability for the tutorship,

- goals and contents of the tutorial including the desired student skills development,

- assessment of whether what has been learned in the tutorial is sufficient for practical implementation in the daily work of the agency,

- assessment of whether the knowledge gained from this work has an impact on later professional life and / or self-employment of the students, and

- general potential of project courses and student associations in higher education.

International Journal of Management and Applied Research, 2020, Vol. 7, No. 4 
In contrast, the questions for the interviews with the two students who attended the course and became involved in the design agency later on considered the following aspects:

- motivation of the students to attend the tutorial,

- assumed role of the instructor of the tutorial,

- assessment of their own skill acquisition,

- assessment of weaknesses or missing skills of the team,

- new content or content which was not learned during the course of study,

- biggest personal gain from the tutorial and the work in the agency,

- assessment of the extent to which the work could possibly prepare them for later professional life and/or self-employed activities,

- eventual recommendation of this experience to other students, and

- barriers to the compatibility of work with their courses of study.

On the basis of a full transcript of each interview, a qualitative data analysis was performed. The results of the interviews are presented in the next section - first from the point of view of the instructor and then from the perspective of the students - and compared with each other. Building on this, the final section provides insights into the effects that training firms can have on entrepreneurship education in general.

\section{Findings}

To find out how informal learning can be structured by instructors using training firms and what effects this has on the preparation of learners for later professional practice and / or self-employment interviews with a course instructor as well as with students attending the course and engaging later on within a training firm were carried out. Thus, the findings allow insights into the two perspectives of teachers and learners in entrepreneurship education via training firms.

\subsection{Staff View}

In view of the instructor perspective, the results have shown that a certain level of motivation is crucial for teaching entrepreneurship in the context of a training firm. Thus, the instructor interviewed was involved in the firm himself during his own studies. The training firm has grown dear to his heart and it is important to him that the firm will continue. He passes this spirit on to his students. In addition to his own involvement in the project and thus his role model function for the students, the instructor also has teaching experience at the university to which the training firm is linked. His involvement at the university seems to be an important key in assessing the opportunities for collaboration with and support from the home university. It should be further clarified that the design agency analyzed here is not formally part of the university, but was initiated by professors in communication design at the University of Applied Sciences HTW Berlin and has therefore often received orders from the professors and / or other university members in the past.

In addition to a good relationship with the home university, industry knowledge is also a crucial aspect that must be imparted to the students as part of the tutorial if it has not already been acquired during the course of study. Here, too, I would like to add briefly

International Journal of Management and Applied Research, 2020, Vol. 7, No. 4 
that the agency was traditionally operated exclusively by students of communication design, but is currently more interdisciplinary - since there are many other tasks to be covered in addition to the actual orders, such as finance, computer technology, personnel recruitment etc. Given the variety of topics and challenges that a student association entails, it is impossible to address all of these aspects as part of a tutorial. It is therefore of crucial importance that the students participating in such a training firm can bring additional knowledge from their studies or from their free time or are at least willing to acquire this knowledge on a voluntary basis beyond the tutorial. For example, you need people who are already successfully self-employed, who know how to speak to clients and who, ideally, have already gained some founding know-how. You also need someone to take over the community interface and keep the team together.

Besides self-directed learning, the tutorial can convey the necessary knowledge about association law, business modeling and structuring as well as market analysis and interaction with former participants and / or other founders for motivation purposes. Despite the contents of the tutorial and a high level of self-motivation of the students participating in the association, it is a challenge to take over the acquisition of orders independently. From the instructor's perspective, it would therefore be advisable if the students could have a mentor, e.g. a professor from the associated university. It is also important that the students see the perspectives of their customers and stakeholders. In addition, for the success of the association in general, business management expertise should be represented in the team and not be underestimated. With regard to the team, it is also important to establish a certain level of reliability in order to reduce fluctuation of team members. This is a particular challenge for non-university and voluntary activities in general.

Decisive advantages that students take with them to their later professional life if they have volunteered in a student association during their studies are for example a high level of practical experience, a good network within the respective industry, knowledge of self-employed activities and relevant experience with team work as well as management experience. All in all, student start-ups offer the possibility of experimentation within the safe surroundings of the home university with no real pressure on the results. In addition, interdisciplinary work is of great relevance when students from different fields of study work together within a student association. This broadens their perspective beyond subject boundaries more than any interdisciplinary project course could.

\subsection{Student View}

With regard to the student view, the results have shown that personal motivation plays a major role in the decision to become involved in a student association. Thus, one of the students interviewed was recruited by a friend who was already participating in the tutorial, and another one was motivated by his girlfriend to volunteer. All in all, the students highlight the relevance of the preparation tutorial. This is were they gained knowledge of how to run a design agency and some initial management know-how. In addition, the role of the tutor who accompanied them on their way to founding their own association was of crucial importance to them. When they managed the association themselves, they realized that - even if everyone is equally involved in the

International Journal of Management and Applied Research, 2020, Vol. 7, No. 4 
agency - a clear division of roles is required. The team now has the following roles: a human resources manager who keeps the team together, a finance manager who monitors the finances, and an IT manager who is responsible for the homepage and backend. In addition, the students would like a lawyer in the team who is well versed in association law.

From the students' point of view, the greatest benefit of the engagement in the association is that on the one hand they can find new friends and on the other hand they can get in touch with potential future customers or employers. Involvement in the agency also prepares them for future self-employment. In this way, concepts tested in the agency can later be used to set up their own businesses. Both students interviewed are very interested in becoming self-employed. One of them has already gained experience as an employee and now sees the advantages of self-employment in flexible working hours and freedom from the decisions of others, especially superiors.

In contrast, compatibility with the course of study and with part-time jobs, which must be pursued in addition to earn money is seen as a challenge. Furthermore, due to constraints caused by their studies and / or additional jobs, everyone can devote different amounts of time to the design agency. In addition, new members have to be recruited. A core team of around five people is currently involved in the association, but eight to sixteen would be better, so that not everyone has to be involved in processing an order but the orders can be split among them. In the following section, from the main findings of the case study, some implications for the development of course concepts for entrepreneurship education and especially training firms will be derived.

\section{Conclusion}

The objective of the present contribution was to find out how informal learning can be structured by instructors with the help of training firms, and what effects this has on the preparation of the learners for later professional practice and / or self-employment. The findings of a case study - a communication design agency for students at the University of Applied Sciences HTW Berlin - presented in the previous section have given some interesting insights. All in all, it can be said that training firms are a suitable method for informal learning in entrepreneurship education. At the same time, this method requires certain framework conditions and places special demands on teachers and learners, which are presented below.

As the study results have shown, the success of a training company mostly depends on the motivation that both teachers and learners bring to the company. In this context, for example trainers can open the door to possible collaborations and structural support at the home university. Furthermore, the teacher should make contact with a suitable mentor who will provide the founding team with professional support in setting up the company. To teach students to understand the perspectives of customers and stakeholders, it would be advisable, for example, to set up an advisory board for the firm with representatives of the respective industry.

International Journal of Management and Applied Research, 2020, Vol. 7, No. 4 
The students participating in such an agency should bring in industry knowledge and / or management competencies. If they do not have this, they should at least be willing to acquire this knowledge on a voluntary basis. In view of the variety of tasks, the team must additionally be willing to distribute and assign different roles. To create fairness among all team members, it would be good to set a minimum number of hours per week for the engagement of each team member. For student start-ups, since it is a voluntary commitment in addition to studying, a minimum team size should be available in order to ensure the successful flourishing of the company in spite of time constraints.

To sum up, the results have shown a best practice example of entrepreneurial training and learning in a university context and the necessary framework conditions, which can be useful for those involved in the development of course concepts for entrepreneurship education. Overall, it can be stated that the advantages of such a commitment clearly outweigh the requirements. Training companies can be seen as an expanded version of volunteering for your own good where the assignments are real but the students are still protected by the home university. In addition to studying, the students receive a high level of practical experience, can build up a good network within the respective branch of business, acquire knowledge of self-employment, management experience and gain relevant experience of teamwork. When they finish their studies, they will already be experienced team workers and will have broadened their perspectives beyond subject boundaries. Furthermore, the students will have made new friends and contacted potential future employers. Some of them may now also feel ready for future self-employment - even if the effects on later professional life and / or self-employment cannot be finally assessed here, since the students interviewed have not yet completed their studies.

From the results of the case study, some implications for future entrepreneurship education practice at German universities can be derived. First, it would be advisable to urgently facilitate and enable the establishment of such training companies by providing staff and funds, including the establishment of an advisory board, etc. Second, volunteering or service learning should be encouraged as forms of informal learning among students, as students who gain practical experience alongside their studies generally feel better prepared for future professional life. In this context, appropriate framework conditions must be created at the universities, for example by including such practical activities as part of the course of study. This would help to ensure that practical activities are no longer an additional burden on the students, but are perceived for what they really are: a great opportunity to apply the skills you have learned during the course of study and to gain real entrepreneurial experience in the protected framework of a university.

There are some limitations of the study, which are summarized here. First, the present work is based on a case study that consists of only three interviews. In order to confirm the results of the present study, a comparison with the effects of training companies on later career choices and / or self-employment at other universities would be advisable. Since the number of training companies focusing on non-business subjects in German university hands is relatively small, training concepts from other countries could also be included in a further analysis. Second, the interviews showed that the students

International Journal of Management and Applied Research, 2020, Vol. 7, No. 4 
interviewed here already had an affinity for entrepreneurship. This is probably due to the fact that engagement in training companies is usually voluntary and takes place outside study, and therefore goes hand in hand with a high level of personal motivation. Thus in terms of future research on training firms, conducting a larger study with students from different disciplines and with a different level of previous knowledge in entrepreneurship would be interesting - also in order to gain more comprehensive insights into the effects that training companies can have on the preparation of learners for later professional practice and / or self-employment.

\section{References}

1. Blackwood, T.; Baty, G.; Dale, B.; Fowle, M.; Hatt, L.; Jussila, N.; Pugalis, L. (2015), Team Academy Northumbria-Learn to Surprise Yourself, York: The Higher Education Academy

2. Blumenfeldt, P. C.; Solowell, E.; Marx, R. W.; Krajcik, J. S.; Guzdial, M. and Palincsar, A. (1991) "Motivating project-based learning: sustaining the doing, supporting the learning", Educational Psychologist, Vol. 26, No. 3 \&4, pp. 369398. https://doi.org/10.1080/00461520.1991.9653139

3. Ebbers, I. (2004) Wirtschaftsdidaktisch geleitete Unternehmenssimulation im Rahmen der Förderung von Existenzgründungen aus Hochschulen, FGF Entrepreuneurship-Research Monographien: No. 42, Josef Eul Verlag, Köln.

4. Fowle, M. and Jussila, N. (2016) "The Adoption of a Finnish Learning Model in the UK", Paper presented at 11th European Conference on Innovation and Entrepreneurship: ECIE 2016, Finland: JAMK University of Applied Science, 1516 Sept 2016.

5. Hills, G. E.; Hultman, C. M.; Miles M. P. (2007) "Entrepreneurial marketing and university education", in: Fayolle, A. (ed.) Handbook of research in entrepreneurship education, Volume 1, Cheltenham: Edward Elgar, pp. 219-229. https://doi.org/10.4337/9781847205377.00022

6. Lackéus, M. and Williams Middleton, K. (2018), "Assessing experiential entrepreneurship education: key insights from five methods in use at a venture creation programme", in: Hyams-Ssekasi D, Caldwell EF (eds) Experiential Learning for Entrepreneurship. Theoretical and Practical Perspectives on Enterprise Education, Palgrave Macmillan: Cham, pp. 19-50. https://doi.org/10.1007/978-3-319-90005-6_2

7. Levie, J. (1999), Entrepreneurship education in higher education in England: A survey, UK: Department for Education and Employment.

8. Linton, G. and Klinton, M. (2019) "University entrepreneurship education: a design thinking approach to learning", Journal of Innovation and Entrepreneurship, Vol. 8, No. 3, pp. 1-11. https://doi.org/10.1186/s13731-0180098-z

International Journal of Management and Applied Research, 2020, Vol. 7, No. 4 
9. Manimala, M. J.; Thomas, P. (2017) "Entrepreneurship education: innovations and best practices", in: Manimala, M. J. and Thomas, P. (eds.) Entrepreneurship education: Experiments with curriculum, pedagogy and target groups, Singapore: Springer, Wiesbaden, pp. 3-53. https://doi.org/10.1007/978-981-10-3319-3_1

10. Mueller-Camen, M.; Salzgeber, S. (2005) "Changes in academic work and the chair regime: the case of German business administration academics", Organization Studies, Vol. 26, No. 2, pp. 271-290. https://doi.org/10.1177/0170840605049802

11. Overwien, B. (2009) "Informelles Lernen. Definition und Forschungsansätze", in: Brodowski, M.; Devers-Kanoglu, U.; Overwien, B.; Rohs, M.; Salinger, S; Walser M. (eds.) Informelles Lernen und Bildung für eine nachhaltige Entwicklung. Beiträge aus Theorie und Praxis, Verlag Barbara Budrich, Opladen \& Farmington Hills, pp. 23-34.

12. Pittz, T (2014) "A model for experiential entrepreneurship education", Journal of Business and Entrepreneurship, Vol. 26, No. 1, pp. 179-192.

13. Sehen und ernten e.V. (2020), Design Agency [online], Available from: https://www.sehenundernten.org/, [Accessed on 19 March 2020].

14. Steinke, I. (2012) "Gütekriterien qualitativer Forschung", in Flick, U.; von Kardorff, E.; Steinke, I. (ed.) Qualitative Forschung. Ein Handbuch. Originalausgabe, 11th Edition, Reinbek (Hamburg), Rowohlt Taschenbuch Verlag, pp. 319-331.

15. Sukavejworakit, K; Promsiri, T.; Virasa, T. (2018) "OETEL: An innovative teaching model for entrepreneurship education", Journal of Entrepreneurship Education, Vol. 21, No. 2, pp. 1-6.

International Journal of Management and Applied Research, 2020, Vol. 7, No. 4 